\title{
The Divine Feminine Presence in Ibn ‘Arabi and Moses de Leon
}

\author{
Julia Alonso
}

check for updates

Citation: Alonso, Julia. 2021. The Divine Feminine Presence in Ibn 'Arabi and Moses de Leon. Religions 12: 156. https://doi.org/10.3390/ rel12030156

Academic Editor: Cristobal Serran-Pagan Y Fuentes

Received: 15 January 2021 Accepted: 19 February 2021 Published: 27 February 2021

Publisher's Note: MDPI stays neutral with regard to jurisdictional claims in published maps and institutional affiliations.

Copyright: (c) 2021 by the author. Licensee MDPI, Basel, Switzerland. This article is an open access article distributed under the terms and conditions of the Creative Commons Attribution (CC BY) license (https:// creativecommons.org/licenses/by/ $4.0 /)$.
Vicerrectorado Investigación, Cátedra Internacional De Hermenéutica Crítica: Hercritia, National Distance Education University (UNED), 28015 Madrid, Spain; julia.alonso.dieguez@gmail.com

\begin{abstract}
This paper is an investigation of the divine feminine power as depicted in the texts of Hispanic mystics from Sufi, Hebrew, and Christian traditions. This work is intended to investigate the origin and subsequent development of a transcendent reconciliation of polarity, its diverse manifestations, and the attainment of a common goal, the quintessential of the Perfect Human Being. The architect of the encounter that leads to Union is "Sophia". She is the Secret. Only those who are able to discern Her own immeasurable dimension may contemplate the Lady who dwells in the sacred geometry of the abyss. Sophia is linked to the hermetic Word, She is allusive, clandestine, poetic, and pregnant with symbols, gnostic resonances, and musical murmurs that conduct the "traveler" through dwellings and stations towards an ancient Sophianic knowledge that leads to the "germinal vesicle", the "inner wine cellar", to the Initium, to the Motherland. She is the Mater filius sapientae, who through an alchemical transmutation becomes a song to the absent Sophia whose Presence can only be intuited. Present throughout the Creation, Sophia is the axis around which the poetics of the Taryuman al-ashwaq rotates and the kabbalistic Tree of Life is structured.
\end{abstract}

Keywords: Sophia; Duende; union; Eros; path; feminine power; heart; Presence; secret; theophany; Hieros Gamos

\section{Introduction}

Those born in present-day Spain, whose Islamic and Jewish history has been concealed from us, have a responsibility to discover our long-neglected authors, the ones who wrote in other languages-Hebrew and Arabic. For centuries, their linguistic and cultural perceptions shaped the ways of life and interpretations of the world that, in conjunction, gave rise to that crucible of knowledge, the Andalusian world [andalusí], characterized by riches and originality. As Fernando Mora says, "It is an 'old vernacular disease' to think that our cultural background consists exclusively of texts written in Spanish" (Mora 2019, pp. 15-29). And it was the Spanish historian Sánchez Albornoz, in his book Spain: a historical enigma, who declared that Ibn al "Arabi is "the personification of a Spaniard". (Mora 2019, pp. 15-29). The same can be said of Moses de Leon.

The purpose of this article is to address the subject of investigation within a broad historico-religious context whose written manifestation, as we know from Noah Kramer's translation of the Sumerian hymns, dates back to the bridal rite of (Ryan 2008, p. 7) Hieros Gamos $^{1}$. To support the thesis of a common origin of the mystics linked to our authors, it is necessary to investigate the symbolic concurrences, exegesis, ${ }^{2}$ and the process employed by each of these hermeneutical seekers whose object is to gain access to Supreme Knowledge, in which Sophia plays the primary role.

The present investigation reveals the exceedingly ancient Presence of a Feminine Power of Divinity, as displayed in diverse currents that shaped the many religious, spiritual,

1 See: (Kramer 2001). Sacred sexual intercourse is thought to have been common in the Ancient Near East as a form of "Sacred Marriage" or hieros gamos between the kings of a Sumerian city-states and the High Priestesses of Inanna, the Sumerian goddess of love, fertility and warfare. See: (Vázquez 2007).

2 The Zohar is an esoteric and mystical exegesis of the Torah, by means of the sacred value of its letters. Ibn 'Arabi, for his part, wrote an exegesis of his Interpreter of Desires, in which he elucidates the hidden meaning of the text. 
and philosophical movements coexisting within Al-Andalus. Within that framework, despite a certain friction, Muslims and Hebrews were able to project their interpretation of spirituality and divine structure into Christian mystical theology, where it gave rise to a powerful and unique way of Knowledge whose originality consisted in the vision of a force emanating from the celestial order. This emanation results in a differentiated polarity that includes, yet transcends, the amorous entanglement that leads to an encounter with Unity. It is thus that a sort of irruption occurs within Hispanic mystical life, where the figure of Sophia linked to Love acquires enormous power and a singular means of expression. It is proposed to describe this original manifestation within the borders of Al-Andalus, focusing on the intimacy generated between the seeker and the Creative Force and on the ways in which this encounter is described in the three languages linked to the religions of the Book: Arabic, Hebrew, and Spanish. Underlying the Presence and manifestation of the Creative Force (known by various names, and to our authors as Ibn 'Arabi's, Himma, Moses de León's, Shekhinah, and St. John of the Cross', Wisdom), is the Science of Letters, ${ }^{3}$ the knowledge of harmonic sounds, number, and sacred mathematics.

That said, the goal of this work will be to highlight the equilibrium of the Divine, the celestial hieros gamos that is projected into the human soul and into the Creation in a continuous circular flow, embracing differences and weaving them into a single manifestation that reflects, like a mirror, the unsayable.

The hypothesis is that diverse mystical paths suggest the existence of a universal entanglement that can be discovered by apparently divergent pathways, all leading to a common goal: intuitive, noetic knowledge. To those who undertake the voyage into uncertainty, Sophia grants this particular kind of knowledge in the form of Light. The current proposal will emphasize the original Unity, the power of the Cosmic Eros that guides the enamored soul toward an "experience" that takes place in dimensions of reality beyond time and space, incorporating harmonies and discrepancies, encounters and disencounters that emerge in an intermediary world between the spiritual and the material: the world of the soul.

It seems essential to investigate, beyond an anthropocentric and unidirectional vision, the relationship of the human being with Longing, with the Presence of a mysterious Saudade, ${ }^{4}$ and definitively with the seductive figure of Sophia, who precipitates those who "suffer" from love-sickness into another dimension. This perspective will necessitate a search for cultural variations in varying contexts, perhaps even a sacred language that connects us to all the inhabitants of the universe, in an attempt to reveal the common indicators underlying the diverse interpretations and expressions and their hidden messages. Something is summoning us, challenging us, calling attention to the paths that coincide with this search, to the convergence of itineraries that guides us to the fulfillment of a lack. The present study will examine, in short, the common threads and concurrences that speak to us of a community formed around the sacred lineage of gnosis, which inhabits a very particular spiritual and contemplative cartography. Despite the diversity of perspectives and historical or cultural dissonances, it calls our attention to the sense of a universal gnostic communion. As the Murcian Sufi Ibn 'Arabi reminds us, the mystic souls of all historical epochs live out the same spiritual experience, though conditioned by the diversity of beliefs, by religious plurality. This diversity gives rise to what the Sheikh denominates as "the god created through the creeds", which is inevitably problematic, since according to a proverbial saying: "There are as many ways to God as there are human souls" (Chittick 2003, p. 7). It is precisely Ibn 'Arabi who emphasizes the diversity of opinions (Chittick

\footnotetext{
See: footnote 16
}

4 See: (Borges 2008); De Sa 'Carneiro Mario, No lado esquerdo da alma, 2a ed. Alma Azul, Coimbra 2004, p. 38; Pereira Dacosta Dalila, Encontro na noite, Lello \& Irmão Editores, Porto 1973.

https:/ / www.ler.letras.up.pt/uploads/ficheiros/17602.pdf (accessed on 12 December 2020).

Saudade is a Galician-Portuguese term and is therefore Iberian. There is no direct translation into English. It is an ardent desire or longing to return to the origin, which implies a deep sense of loss of an initial state of fullness in unity. This results in an emotional state of profound nostalgia or melancholia, predicated on the absence of a beloved person, place, object, or state of being. 
2003, pp. 8-9) (mas'ala jilāf) that, according to him, has been established by the working of the divine Wisdom and Compassion; as he points out, "God himself is the source of all the diversity in the Cosmos" (Chittick 2003, pp. 8-9). Consequently, the Murcian master considers all creeds, even the discordant ones, as emanating from the same god, since they, as well as the variety of methodological perspectives, all contribute something vital. It requires only a certain effort to distance ourselves from our habitual epistemological framework in order to situate ourselves on another plane on which, according to the professor Teresa Oñate y Zubia, there occurs the coupling of differences, of masculine/feminine, light/darkness, above/below, dense/subtle.

When considering the mystical phenomenon within the geographical boundaries of Spain, Federico García Lorca's writings on duende are indispensable. It was the great Andalusian poet and dramatist who delineated the particular characteristics of the creators and seers native to this terrain in terms of their connection with duende, an overwhelming, indescribable, and irresistible Presence. This duende is nothing less than the relevant, magical divine feminine power that emerges in the texts of these Spanish mystics, leading through Sophia and her Wisdom to an intimate and theosophical encounter.

Thirteenth-century Spain experienced a very particular outburst of the mystical phenomenon, and any attempt to decipher the key points of the spiritual paths that channeled it demands the closest observation of the poetic and hermeneutic word, bearer of life yet foreign to rational discourse. A notable example would be the language of St. John of the Cross, where something that at first seems like nonsense turns out to be a cipher, a symbol, a key to unknown gateways and dimensions. Through this riddling use of language, the saint explored differentiated planes of reality: imaginal worlds, as in his Strange Isles ${ }^{5}$ (Ínsulas Extrañas), or topographies of the frontiers where we find a phenomenology pregnant with sightings, revelations, locutions, visions, and other portents peculiar to the alchemical transmutation experienced by the Gnostic. These experiences foment the emergence of poetic language, allegory, and symbol, essential vehicles of a shared, alternative way of knowing linked to noesis. ${ }^{6}$

It is also necessary to consider other texts, far removed in time, in which we detect antecedents and fundamental parallelisms and where we confront reflections on Wisdom, that universal, millenary notion that penetrates the Hispanic theology of the Sufi, Hebrew, and Christian mystics. In examining the origins and later development of a certain sacred transcendent polarity, one discovers that complementary categories replace the oppositional ones, effecting, a conciliatory coupling that is projected through various manifestations and leads at last to the achievement of a goal common to all three "mystics of the Book": the Perfect Human Being. This Hispanic "symbolic nuptial process" is clearly opposed to the Rhenish "mystical theology of the essences", although some of its aspects-like those related to the Unsayable and Unthinkable, that Nothing that is Everything, the Divine Darkness of Dionysius the Areopagite may occasionally converge. Varying linguistic and cultural codes account for the disparity between particular approaches, but it is evident that these mystics are following parallel, not divergent, routes. Their discursive results, occasionally influenced by dogmas and theologies, arise from interpretations of their sacred texts.

The Hispanic mystical paths are diverse (centuries later the Sufis and the adherents of the Kabbalah were to contribute to the Christian mysticism of St. Teresa, St. John of the Cross, and Miguel de Molinos); however, all refer to biblical texts, sometimes amplified by millenary currents already evident in the Sumero-Akkadian hymns ${ }^{7}$ whose defining characteristics were perpetuated in the Song of Songs. The metaphors, analogies, and double mean-

\footnotetext{
5 Saint John of Cross: "strange isles" are analogous to Ibn 'Arabi's dimension of active imagination. It is in this intermediate state between the terrestrial and the celestial that visions, prophecies, and locutions occur.

6 The Greek term vónбıৎ refers to a "visión, intuition, intellection". Noesis is the mental activity ("nous") through which one accedes to a direct and unmediated knowledge of an object.

7 See: Noah Kramer Samuel, From the Poetry of Summer, Berkeley, University of Berkeley Press, 1979, p. 71; Noah Kramer Samuel, The Sacred Marriage Rite, Bloomington, Indiana, University of Indiana Press, 1969; Graves Robert, La Diosa Blanca, Madrid, Alianza Editorial. 1996; p. 500.
} 
ings of that supreme example of an erotico-spiritual text were in turn reflected both in the Tarjumán al-Ashwáq (The Interpreter of Desires) of the Murcian sheikh, Muhyiddin Muhammad Ibn al-Arabi الطائي الحاتمي عربي بن محمد بن علي بن محمد اله عبد أبو, Murcia, 28 July 1165Damascus, 16 November 1240), and in the Zohar attributed to the Spaniard Moses de León (?1240-Arévalo, 1305), known in Hebrew as Moshe ben Shem-Tov (ליאון-די טוב-שםבן משה). These texts describe the milestones of a spiritual journey with a common goal: the Union of the seemingly diverse, which is attained after an extremely personal itinerary that proceeds through dwellings, steps, stations, and wine cellars before arriving at Ibn 'Arabi's "Dwelling of Non-Dwelling", or at the Zohar's "Opening of the Eyes", a station similar to the Seventh Wine Cellar of St. John of the Cross. In these mystics, this entire process is conveyed through an array of connections, attributes, categories and Names that contain a multitude of meanings in which it can be detect echoes of not only the Song of Songs 8 and other biblical texts but of the Sumero-Akkadian Hymns (3400 B.C.) whether anonymous or attributed to the Akkadian priestess Enheduanna (2285-2250 B. C), in which the transforming Feminine Presence of the Divine plays a central role.

\section{Spanish Mystical Theology: A Mystical Theology with Duende}

What is duende $e^{9}$ ? Only someone who is conscious of its Presence, which dwells in the heart and liberates the creative force that is inherent to it will be able to decipher The Interpreter of Desires, the Zohar, and The Spiritual Canticle. Duende seizes on the mystic writer and on the poet, emptying the heart of refletive thought. Duende is related to the Socratic daimon. ${ }^{10}$ It pillages the soul and obliterates meaning, yet preserves the logic of reason even while transcending it, leading to the emergence of a "poetic rationality", as María Zambrano once maintained (El Hombre y lo Divino, Filosofía y Poesía). It is thus that Spanish philosophy, poetry, and symbolic texts invoke an obscure depth inhabited by the divine, the home of duende. Poetic Reason understands truth not as an adjustment to the facts of physical reality, but as revelation. Therefore, when mystics or poets communicate their revelation in writing, what occurs is the unveiling of a symbolic, transcendent truth from personal experience, destined to attain "the universal": the Unity of Being. As Zambrano says, poetic reason is a "half-awake thinking". It belongs to a liminal space in which the human being is neither awake nor asleep. That topography corresponds to the imaginal world, which the "pilgrim" enters by way of the kingdom of Intermediary Being.

As previously indicated, the supreme theorist of the Hispanic duende was Federico García Lorca (Farré 1998, p. 82), who outlined his theory in a conference he gave in Buenos Aires and Havana in 1933. We defer to him. Our great poet reflects very beautifully and poetically on the notion of duende, an idea linked to the Spain of a sensitive, poetic, impassioned, and overwhelming sentiment. It is normal, in reference to Lorca, that in referring to any splendid and sublime artistic creation one says, in our country, "it has a

8 On the Song of Songs and its relationship to the Sumerian hymns, see p. 9, 11. 318-26.

9 The Spanish word is close to untranslatable and has been adopted into the English lexicon. In reference to the notion of "Duende", the importance of this term lies in its summation of the particularity of all Hispanic art and thought. It is the "Duende," or Daimon, as masterfully described by Lorca, that inspires poetry, dance, painting, and philosophy. This concept is fundamental to an understanding of the consistency between the Zohar and the Interpreter of Desires, as the underlying principle of both texts is precisely this "magical and creative presence". Although it is unnecessary to expand throughout the article on the meaning of this term, it is indispensable to note that the spirit that pervades Duende is a key that unlocks the dimension of the active creative imagination where eroticism and the amorous mysticism meet.

10 Platón, El Banquete, Obras completas, Edic. Patricio de Azcárate, tomo 5, Madrid 1871, p. 293:

"The Daimons occupy the intermediary space that separates heaven from earth; they are the link that unites the Great All with the human being. Since the Divinity never communicates directly with human beings, it is through the mediation of the Daimons (in Greek, $\delta \alpha i \mu \omega v)$ that the divine Voice is transmitted. It is an intermediary between the subtle, or spiritual, and the material dimension. Socrates associates the Daimon with an inner voice."

There are many references to the Daimon in Plato's Symposium: "The divinity does not establish direct contact with men, but it is through this Daimon that every relationship and dialogue between gods and men occurs, both in sleeping and waking". "The proper function of the Daimon is to serve as an interpreter between gods and men, carrying the vows and homage of mortals from earth to heaven, and the commands and blessings of the gods from heaven to earth. This is why Love maintains harmony between the human sphere and the divine, and along with the other daimons, it is the link to the All." 
lot of duende" (Lorca 2003). The author of Blood Wedding puts these words in the mouth of Manuel Torres, who, after hearing Manuel de Falla's interpretation of his Nocturno de Generalife [Nights in the Gardens of Spain], pronounces this magnificent sentence: "Anything that sounds dark has duende" (Lorca 2003). And listening and darkness always accompany duende, as they do those mystic states in which light is born out of darkness to the accompaniment of the harmonic sound of silence, the "sonorous silence" of St. John of the Cross. García Lorca (Lorca 2003) notes, in this sense, that "these dark sounds are the mystery, the roots sunk in the mire that we all know and we all ignore, but from which we receive everything that matters in art". He is referring to the hidden place that Gaston Bachelard (Bachelard 2000, p. 40) describes as "the sub-basements of the soul". That unknown place, that point within the heart, is the dwelling of every soul that allows itself to be penetrated in solitude by a "mysterious Power that everyone feels and that no philosopher can explain" (Lorca 2003).

This is the power that raises the indigent human from hearing to vision, and bestows on the pilgrim the eyes of the Creator, in a Return that deprives the sentient being of action and conceptual discourse. Thus, darkness, hearing, and mystery correspond to their etymological meanings: $\grave{\alpha}-\mu \alpha v \rho o ́ \zeta$ (invisible, somber, obscure, blind); $\dot{\alpha}$ kov́w (to pay attention, to hear a call, to be put to the test); and $\mu \nu \sigma \tau \eta \dot{\eta} \rho \circ v$ (arcane, secret, secret doctrine, secret cult). Duende assumes the function of a power receptive, obscure and mysterious, feminine, impassioned, committed, and creative. It remains remote from any action except those that provoke a rebirth deriving from an inner trauma, and in the process of rebirth, it destroys the self, which is annihilated by its seductive and demanding potency. It is a receptacle, a goblet whose contours are greater or lesser according to the content of the stored-up force and its insistent pulsations. Consequently, for the poet from Granada, "Duende is a power and not a labor, a struggle and not a thought". Duende, he says, "is not in the throat (from which sounds emerge): it rises inwardly from the soles of the feet" (Lorca 2003); and, as can be observed, it bursts forth in a delirium of song, poetry, and celestial harmony unrelated to earthly human concordances. Although it operates in a realm beyond the mundane, nevertheless, through an irradiation of the Good and the Beautiful, the Presence of this force alters the nature of the most ordinary experience. From this point of view, one can speak of a relationship with the transcendent in terms of love and passion.

The duende whose summons Lorca so eloquently describes resonates throughout Spanish mystical theology: vibrant, enigmatic, hermetic, and seemingly incoherent. For each individual, it is unique, inviting us to different paths, as many as there are human souls. Duende makes use of an obscure, audible, and mysterious desire, manifesting through signs engendered by Sophia. Anyone capable of capturing something of its excessive force trembles before it. In order to understand texts produced within this state, we need a symbolic hermeneutics whose goal is "festival", in the sense defined by Hans Georg Gadamer in Truth and Method and The Beauty of the Word. The sacred word is a milestone on the path, leaving coded messages; it sidles downward to the crypts of the soul along a spiral staircase that descends in a serpentine path towards the darkness where light is most concentrated. Undertaking this risky descent, the pilgrim discovers that it is, astonishingly, an ascent (see Kingsley 2016) toward an encounter within an "inner Castle" (Saint Thérèse of Avila.), which harbors a diamond, in a Templum, a palace of perfection, reached through states and stations or dwellings. In this displacement toward the heights of oneself, the duende, the Socratic daimon, impels the traveler who, like Odysseus, must pass the stormy seas in order to reach home: the point of origin, the Unity. It is not free from suffering, this voyage, because it requires a stripping away, a total abandonment, even of the ego itself, in order to reach, egoless, annihilated, the primordial I, the Jungian Self.

Duende knows the instant because it occurs within it. It emerges from an eternal un-time and interrupts chronological succession. Its Presence irrupts in the Kairós, an "opportune" time. Tearing the human being away from the known self, it suspends the quotidian, revealing subtle pathways that bifurcate in search of the bridegroom: God. Some 
of these pathways penetrate into an imaginal, intermediary world, the barzakh, in which, as Ibn 'Arabi (who, like Moses de León, was familiar with the Science of Letters) tells us, "the bodies are spiritualized and the souls materialized". Alternatively, they may travel through "Strange Isles" (as St. John of the Cross suggests) thanks to another "science of words", the sonorous play of alliteration; or they may end up conforming to an almost Riemannian geometry, ${ }^{11}$ the Tree of Life, related to a sacred mathematics of the word, an alpha-numeric code known as Gematria, ${ }^{12}$ as Moses de León insinuates.

Duende invariably arrives spontaneously, at just the right moment, when the ground has been prepared and the ego has learned to let go of itself, as the Portuguese poet Fernando Pessoa (1888-1935) informs us through the heteronymous master Alberto Caeiro (Pessoa 2001, p. 82). Duende cannot be invoked; it lays down no pathways; it simply bursts forth, transmitting to the subject who experiences it, in the words of Kierkegaard (1813-1855), "a searing atom of eternity". In this respect, Federico García Lorca (1898-1936) writes, "One only knows that the blood burns as if inflamed by an embrocation of broken glass, that duende exhausts, that it rejects a gentle, familiar geometry, that it disrupts styles" (Lorca 2003). The arrival of duende is closely related to death, a death in life, since, as the poet from Granada tells us, “duende won't come without the possibility of death, if one doesn't know that it is already prowling around one's house, if one isn't sure that it will shake those branches that we are all carrying and leave us inconsolable" (Lorca 2003). Duende is attracted to the very edge of the pit, in open war with the creator (Lorca 2003). It moves through a horizon of events, bearer of the mystery of a "naked feminine and re-creative singularity" that inhabits every soul. Spain, says García Lorca, is the only country in which "death has become a national spectacle, where death greets spring with long bugle calls, and its art is always ruled by a heightened duende that renders it distinctive and inventive" (Lorca 2003). Death comes to the lovesick, the wounded heart. St. John of the Cross says, "Love is like dying". "The wound and dying are two ways of suffering death" (Cruz 2002, Cc. 7: 3,4,5, pp. 764-65).

Appropriating an expression of Lorca's, and referring to Saint Thérèse of Ávila, it can be affirmed that the Sufi master Ibn 'Arabi of Murcia, the Hebrew Moses de León, and the Christian mystic St. John of the Cross, were all "in-duended", possessed by duende, enamored of an unsayable that summoned them through that indescribable impulse: the desire that awakes Eros in all of creation. There is an extract in the Zohar that speaks, like the Song of Songs, of a "Love strong as death, hard as the parting of the soul from the body" (Laitman 2015, p. 204), and that severing presupposes a lack, a longing, a discontent, a fatal attraction that impels the human being beyond reason and disjunctive logic. Love has wings, it raises its creatures above the everyday; it delights in risk, accepts suffering, leads to the invisible, brings upper and lower worlds into conjunction. And the "kiss of Love", in one paragraph of the Zohar, is said to "expand in the four directions and the four directions join together and unite" (Laitman 2015, p. 204). That death accompanying a spiritual

11 Bernhard Riemann's (1826-1866) interest was not limited to flat, plane two-dimensional surfaces inhabited by the triangle and the circle, nor to the three-dimensional spaces inhabited by the cube and the sphere, nor even to four-dimensional mathematical spaces (difficult to visualize, but possible to define and manipulate mathematically). He was also engaged in characterizing "n-dimensional spaces," which makes the Riemannian methodology much more universal than previous concepts of geometry. Exactly like the imaginal world of the mystics, Riemann's conception concerns unbounded spaces capable of containing an infinite number of dimensions, in particular the dimension of the Barzakh, in which, as Ibn 'Arabi affirms, bodies are spiritualized and spirits materialized.

12 Gematria is an ancestor of numerology. It originated among the Syrians, Babylonians, and Greeks but was pursued assiduously within Jewish mysticism, and particularly in kabbalistic studies. In Gematria, a certain value is assigned to each letter of the alphabet. The Hebrew Kabbalists said that "Belzebiel", the builder of the Tabernacle, was an initiate of Gematria, or the relationship between words and numbers and their effect on both heaven and earth. By adding up the value of the letters within a word, one obtains another number and a meaning, which is then compared with the total numerical value of other words.

For students of the Kabbalah, the divine creation is based on the power of Hebrew words and letters, as well as the numbers associated with them. There is also an Islamic Kabbalah, similarly associated with the Science of Letters, and practiced by Ibn 'Arabi. See Note 16 in this article.

The body of the invisible God materializes in the letters of the Torah, an icon of the invisible in which the numbers and the letters converge. God reveals himself to the Kabbalist, the illuminated exegete, as a secret, both in interior reality and in the esoteric sense.

See Gamliel Belk Akiva, Gematria And Mysticism in Genesis (Journey Through Genesis Book 1), B’Nai Toach Institute, LLC, Miussouri, 2012: http/ / www.bnti.us (accessed on 21 June 2020). 
journey, in Ibn 'Arabi's (Chittick 2003, pp. 70-71) opinion, presupposes the abandonment of characteristically human limitations, so that the individual becomes "erased", or in the words of St. John of the Cross, "effaced", and within that "annihilation", nothing remains, according to Ibn 'Arabi, except the face of the Wujud (Chittick 2003, pp. 70-71), turned toward the Creation.

Lorca asks, And where is Duende? "Through the empty arc there enters a mental breeze that blows insistently over the heads of the dead, searching for new landscapes and unknown accents: a breeze that smells of a child's saliva, of bruised grass and the stinging medusa's veil, that announces the continual baptism of newly created things".

In sum Ibn 'Arabi, Moses de León and St. John of the Cross are captives of a duende that speaks of dying of love, of surrender and personal extinction. That is the only way to understand Ibn 'Arabi's nocturnal "Journey to the Lord of Power"; the Zohar's "Opening of the Eyes", the "I die of not dying" of St. John of the Cross, and Santa Teresa's "I live without living in myself".

\section{The Supremacy of the Mystical Nuptial: Antecedents}

The Great Queen (NINGAL) of queens born for the rightful Me,

born of a fate-laden body,

you are even greater than your own mother,

full of wisdom, foresight, queen over all lands,

who allows existence to many,

I now strike up your fate-determining song!

All powerful divinity suitable for the ME,

That which you have said magnificently is the most powerful!

Of unfathomable heart, oh highly driven woman

of radiant heart, your ME, I will list for you now! (Vázquez 2016, vss. 60-65)

The texts of ibn 'Arabi's Interpreter of Desires and of the Zohar attributed to Moses de León contain ancient wedding images derived from the cult of the Feminine Power of Divinity.

The first written testimonies of the heavenly wedding and its projection in the earthly order are originated in Sumer. The mythico-theosophical system of Mesopotamian and Egyptian religions, which was inherited by the Mediterranean culture, consists of an internal structure based on a reconciliation of sexual polarities. Therefore, at the heart of the divinity there is a dynamism imbued with eroticism and seduction. The channels established between the higher worlds and the one inhabited by created beings are generated by the projection of that bi-directional desire. True, the disparity and diversity of the models, as well as cultural tensions and their conceptual complexities, display remarkable differences, but from the Hispanic perspective, the most striking phenomenon is the existence of several paradigms of mystical eroticism that share a common theme: the Union of the Holy (masculine), with its Divine Presence (feminine).

To establish this fact, it will be necessary to return to the primal origins of the feminization of an aspect of the Divinity related to desire, love, and the creation of the universe; and which is, in addition, the depository of the laws that govern it. Noah Kramer's works, The Sacred Marriage Rite (Wolkstein 1983, p. 62), History begins in Summer (Kramer 2010), and Inanna Queen of Heaven and Hearth (Kramer and Wolkstein 1983, p. 107), contain numerous poems about the courtship of the Sumerian goddess Inanna and her betrothal to her husband Dumuzi, as well as accounts of the deity's descent into the Underworld ("Inanna and Dumuzi", "Inanna queen of heaven and hearth"). While the first cuneiform texts describe the earthly erotic tensions of the nubile goddess, in those hymns that depict her journey to the underworld the divine Inanna, in her maturity, is obliged to pass through seven successive gates. To gain passage through each one, she must abandon something precious to her, until at the last she remains totally naked and silent, as the laws of the underworld 
are implacable. Nothing remains in her heart except an intense desire for rebirth. In this poem we find the three characteristic phases of the female power: the young woman, the mature woman, and the crone. These three figures could be correlated, in turn, with the three Marys of the Gnostic Gospel of Philip and with the three Seefiroth of the Zohar's Tree of Life: the Mother, Binah; the wife, Tiferet; and the daughter, Malkuth.

In the case of St. John of the Cross, there are also three female representations: the Soul (Spiritual Canticle); the Church (Romance 4; pp. 150-55) (as the bride of Christ, similar to the Community of Israel, Keneset Yi-ra-el); and Wisdom herself (Spiritual Canticle), associated with a higher realm, the breath of the Holy Spirit. This indicates the fundamental importance of these ancient bridal images in the development of a Hispanic mysticism that incorporates the three currents that demarcated the relationships between God and human beings. The entire mystical journey is oriented toward that encounter, the union of opposites, which — despite the various forms it may assume-is never destructive. Instead, it consists of a harmonious entanglement on an equal plane (Cruz 2002, Cc.26,5-13;16-17, pp. 842-47) or even of a reversal of roles, as St. John of the Cross' commentary on the Spiritual Canticle demonstrates (Cruz 2002, Cc. 27,1, p. 848).

In this respect, it is appropriate to add that, contrary to current opinion, parity between the two celestial polarities was quite common in the religions of the near East, and markedly so in primordial erotic relations. At the same time, we note a strikingly explicit description in the Sefiroth of the Tree of Life in the Zohar (see Section 5 of this article), in that the male projections of the right branch of the Tree may at some point take on a female role or vice versa, so that the amatory functions are often interchangeable, which indicates that there is no radical separation of "genders" in this matter. Something similar occurs in the texts of St. John of the Cross ${ }^{13}$ in relation to the figure of Wisdom, which sometimes resembles Christ. As for Ibn 'Arabi, he draws no distinction between the Lord and the Lady (Corbin 1958, p. 109).

In regard to the historical background, and in accordance with Moshe Idel and other researchers, there are grounds for questioning Gershom Sholem's nationalist thesis which asserts that the divine feminine and creative principle (the Shekhinah of the Kabbalists) first assumes her role at the birth of the Kabbalah. On the contrary, its suspect that it is the contact sustained between the Hebrews and the Sumero-Akkadian culture after the Babylonian exile that explains why the figure of the hieros gamos, in which the amorous female power assumes a leading role, is so deeply imbued in the biblical Song of Songs. That text, in turn, retained an indisputable authority for our three Hispanic mystics. Consequently, it is possible to affirm that the amatory progress derived from these pathways of Spiritual Knowledge clearly originates in the Sumero-Akkadian compositions that inspired the supremely erotic biblical outpouring of the Song of Songs, as well as the remarkable references to the mystical wedding in the Hispanic spiritual traditions linked to the three religions of the Book. As for the distinctive role of the feminine in both the 13th-century texts of the Interpreter of Desires and the Zohar and in the 16th-century Spiritual Canticle, from the Middle Ages onward there is a parallel preeminence of women in western mystical traditions that should not be overlooked.

Arthur Green (Yom et al. 2006, p. 350) defends the unmistakable feminization of the Shekhinah ${ }^{14}$ in the Kabbalah of the thirteenth century, as a Jewish response to the heyday of devotion to Mary in the Western Church of the time. This inevitable transfer and mutual influence might explain, in part, three of the most striking creations of our Hispanic mystics: the powerful representation of the Zohar's Matronita (Patai 1947); the projection of the feminine divine in Nizam (Harmony) in the Interpreter of Desires; and

13 See: Cruz, S Juan Obras Completas, Ruano de la Iglesia Lucinio, Ed. Biblioteca Autores Cristianos, Madrid 2002, Introduction to "Espiritual Canticle"; Hodar Manuél, La Sabiduría en S. Juan de la Cruz, Monte Carmelo, CITeS, Ávila 2011.

14 In a verse from sura Fussilat, it is said, "We will make them see our signs on the horizon and in their souls" (41:53). The meaning of the statement for the Shaykh Al-Akbar is explained in a chapter where he deals with sakina (peace, "serenity," but also, like the Hebrew Shekhinah, the divine "Presence"): the sakina that God sent down for the children of Israel in the Ark of the Covenant [Qu'ran 2:248] "was made to come down in the hearts of believers of Muhammad's community [Qu'ran 3:110] ... " (Chodkiewicz 1993, p. 96). 
the central role of Sophia, which penetrates both creation and the soul in love in the texts of St. John of the Cross. In the prologue to the Interpreter of Desires, Tarŷumān al$A \check{s} w \bar{a} q$, the Murcian Sufi master relates an encounter with the divine feminine (Arabî 2002, pp. 16-19) during one of his circumambulations in Mecca. This apparition gives rise to a cryptic conversation that inspires the first qasida of that mystical-erotic poem. As Carlos Varona (Arabî 2002, pp. 16-19) has emphasized, the composition is organized around the axis of the female protagonist. In fact, the beloved Nizām (Harmony), protagonist of the epithalamion, manifests as an epiphany, a tangible reflection of the unnamable and unsayable Here we have an example of a process in which divinity is revealed by the "emanation" of "celestial archetypes" (Arabî 2002, p. 16). By means of this revelation, indescribable spiritual forces take form and become embodied in creatures. From then on, this process enables Love to attain to the condition of a bearer of "knowledge" (Arabî 2002, p. 101), and "the lover/beloved becomes the paradigm of a beauty beyond comprehension" (Arabî 2002, p. 19).

Just as in Sumer, in the Zohar the "face-to-face" sexual relationship is exalted. Luria (Yom et al. 2006, p. 77) suspects that this is the basis of a cosmogonic principle of continuity that is accessed through Wisdom, itself a transformative genesis. Ibn 'Arabi sustains this same principle, as he avows that "creation is continuous and occurs at every instant, renewing itself" (Chittick 2003, pp. 52-53). In the case of the Sufi master, this convergence between the masculine and the feminine is the cause of a "constant metamorphosis", an alchemical transmutation of the self; therefore, it is also responsible for the continuous and "endless fluctuations" suffered by the heart ( $q a l b)$ and experienced by "perfect human beings" who are subjects of a "self-revelation that is never repeated" (Chittick 2003, p. 52).

The same can be said of the prodigal compliments and laments uttered by the bride, (the soul) in the Spiritual Canticle, where she takes the initiative, just as in the Song of Songs. In his commentary to songs 4 and 5 of the Spiritual Canticle, St. John of the Cross exalts the divine creative act, telling us, in his exegesis of these poems, about the path to Knowledge, which springs from "a concern for creatures" (Cruz 2002, Cc. 5,1, p. 760). This concern arises once the human being has descended/ascended "to the infernal regions", and has acquired self-discernment, a process of rebirth/re-creation described in the Ascent to Mount Carmel. The saint places it above all things, saying "this concern comes first of all, on that spiritual path of a progression toward the knowledge of God" because of "his greatness and excellence" (Cruz 2002, Cc. 5,1, p. 760).

In the Zohar as well, both the descent of the divine and the human ascent driven by the desire for union involve passing through several steps, Sefiroth, which act as screens or veils of the Light of the Creator. Ascending to know oneself, through those ten steps, during which the obstacles that prevent true sight are removed, also implies "being born at every moment of the process". This "birth at every moment", both of God in human creatures and of the creatures in God, is a consequence of the desire for transformation implanted by the Creator in order that the intensive point sheltered in the heart of the desiring self should be unfurled until it attains its goal: the perfect human being, free of restrictions and prejudices, free of self. That is the object of the spiritual path. For all three mystics, it marks the end of all "correction" and re-creation. In the texts under consideration, the "Creation", or rather the "re-creation", autopoiesis, is the result of a divine, feminine, and mysterious exhalation through which a willing, speaking, and living God is revealed through theophanies. Accepting this premise leads us to a new "re-enchantment of the world", to a sacrificial dimension that implies the abandonment of self, by the hand of Sophia, in order to "die" into the primordial Self. This knowledge implies the perception of a state of equilibrium between the two functions of divinity, which in turn permits all creatures to respond to the soul with sympathy, "overflowing with thanks", and "bearing witness", as St. Augustine says, "to the greatness and excellence of God" (Cruz 2002, Cc. 5,1, p. 760 ).

The celestial marriage, the hieros gamos, descended to Earth and denoted the union between the upper and the lower worlds. In this way, two potencies combined to guarantee 
the order of the city and of the universe in a bi-directional movement of ascent (the human being) and descent (the divine). The driving force of this metaphysical dynamic was desire, brother of death, borne by the goddess who let her heart lead her along a path from which no traveler returns. The poet who speaks to us in the Descent of Inanna to the Underworld describes the seven levels of knowledge, which correspond to a host of other dwellings, stations and interior wine-cellars (Cruz 2002, Cc. 26, p. 842) celebrated by our mystics. The first line of the poem The Descent of Inanna says: "From the Great Up she directed her mind to the Great Down", and to the question that the poet Dianne Wolkstein asked N. Kramer: "What exactly does 'mind' mean?", he replied, "Ear", adding that in sum, the words "heard" and "wisdom" mean the same thing. "From the Great Up the goddess, 'opened her ear,' the recipient of wisdom, to the Great Down" (Wolkstein 1983, p. 5). Inner hearing and vision, assume the function of senses that contribute knowledge, giving way later on to prophecy and to visionary states. In Sumerian, then, the "ear" is equivalent to Wisdom and this Wisdom is transmitted precisely through "auditions" and "visions", fundamental theosophical devices in the works of Ibn 'Arabi, Moses de León, and St. John of the Cross. The Song of Songs recapitulates many of the metaphysical figures and symbols of the Sumerian accounts, full of mystery and seduction, such as the gallantries between the spouses, kisses sweet as honey, references to the orchard, to the bridal bed, and particularly to the initiative assumed by the wife. Today, the influence of this biblical text on the mystical vision of Ibn 'Arabi, Moses de León, and St. John of the Cross is widely acknowledged. ${ }^{15}$

A reaffirmation of the deity's power and her entanglement with the male aspect, topics that will recur in later bridal mysticism, is reflected in the hymn of Inanna and the God of Wisdom, topics that will recur in the later bridal mysticism. Thus, we see that the divine Inanna assumes the role of Queen of Heaven "in equality" with Enki, God of Wisdom, who, having "drunk beer" with her, imparts to the Queen (who is both his wife and his daughter) "the secrets": the seven Mé that generate the order of the creation (Kramer and Wolkstein 1983, pp. 101-3) The "journey" of ascent to Heaven also implies a descent, to the $A b z u$, the lower regions. "Water", as a source of life, receives prayer. "Hearing" (Cruz 2002, Cc. 14-15, pp. 793-97) is linked to knowledge. The "festival" derived from the "intoxicating union" implies, in turn, the surrender of her crown, the giving up of all her powers: The poem says (Wolkstein 1983, p. 10),

I, the Queen of Heaven, must visit the God of Wisdom(...)/I must honor Enki, the God of Wisdom, in Eridu./I must say a prayer in the deep fresh waters (Idel 2009, p. 248).» "He, whose ears are widely open, $\mathrm{He}$, who knows the Me, the sacred laws of heaven and earth, Enki, the God of Wisdom, who knows all things ( ... )

As we can see, the goddess assumes a primary role in everything pertaining to Knowledge. The feminine presupposes creative action, dynamism, movement, and the deployment of Wisdom, gifts ceded by the god Enki, husband and father. Similarly, in Proverbs 8, 22-30, there is an explicit reference to the timelessness of the feminine aspect of divinity.

22 Aren't you calling WISDOM? ( ... )

From the beginning, the Lord possessed me;

from before his works began.

15 See: Luce López Baralt (2009): Simbología mística musulmana en San Juan de la Cruz y Santa Teresa de Jesús/Luce López Baralt I Biblioteca Virtual Miguel de Cervantes (cervantesvirtual.com);

Simbología mística musulmana en S. Juan de la Cruz, Biblioteca Virtual Miguel de Cervantes, Alicante 2009, p. 3: Referring to San Juan, López Baralt asserts: "In the case of the reformer, there are traces of Castilian poetry, of the Italianizing trend, of popular speech and song, of divine lyric, of the Song of Songs; this was demonstrated some time ago by Dámaso Alonso, Father Crisógono, María Rosa Lida, Colin Thompson."

(López Baralt 2020). Asedios a lo Indecible, S. Juan de la Cruz canta al éxtasis transformante.

Lucinio Ruano de la Iglesia, Introducción Obras completas S. Juan de la Cruz, Biblioteca Autores cristianos, Madrid 2002.

Juli Peradejordi, El Cantar de los cantares comentado por el Zohar, Ed. Obelisco S. L., 2015.

The "Shir haShirim," or Song of Songs, is a supremely important referent for the Spanish Kabbalah, as indicated in the following quotations from the Zohar: "It is a song that contains all of the Torah," and [It is[ "Kodesh Kodashim," or the Holy of Holies. 
30 I was next to you, ordering everything,

dancing joyfully every day,

always enjoying its Presence.

The "idea" of beauty linked to Wisdom exercises a theophanic function, and it is this intuition that gives rise to the Feminine Creator, where the spiritual and the sensitive converge. As it is already well known, these Platonic texts were adopted by Neoplatonism, a philosophical current that permeates the Türyuman, the Zohar and also the Spiritual Canticle, insofar as it regards the role of divine emanations, which in these texts are linked to the knowledge that Wisdom bestows on the traveler, the seeker.

\section{Ibn Al ‘Arabî: The Interpreter of Desires: Tarŷumān al-Ašwāq}

My heart can assume all forms: a pasture for gazelles, and for the monk a monastery/It is a temple for idols, a Ka'aba for the pilgrim, the Tablets of the Torah and the book of the Qur'an/I follow only the religion of Love, and wherever its camels go I take that way, for Love is my only faith and my only religion. (Arabî 2002, Cas. 11: vss. 13-14-15, p. 125)

Although Ibn al "Arabi, also known as the "the teacher" and dubbed the "Red Sulphur" [aš-Šayj al-Akbar wal-l-Kibrit al-Ahmar], is the author of more than 350 works, one of his many poetical productions deserves separate mention. We refer to The Interpreter of Desires [Tarŷumān al-Ašwāq], whose intimate congruity with the Zohar and the Spiritual Canticle lies precisely in the preeminence of a "mystical wedding" in which the feminine aspect of the divinity plays a leading role. Reynold A. Nicholson translated this work into English in 1911. Later, in 1931, the Arabist Miguel Asín Palacios published his Christianized Islam: a study of Sufism through the works of Abenarabi of Murcia, which marks the beginning of a consideration of the convergence between The Interpreter of Desires and Christian mysticism.

Professor Luce López-Baralt also certainly associates the Canticle with the Interpreter of Desires.

Writers like St. John of the Cross and St. Thérèse of Ávila-to mention only the most exalted figures-reveal an astonishing consanguinity: they share many of their symbols and their most important esoteric mystical language with their Middle-Eastern counterparts. From a literary point of view, this is extremely significant, as it implies that numerous references in the vocabulary of these two Christian saints must be sought among the Sufis. We are faced with the phenomenon of a European literature with numerous literary keys that originate in Arab, and even Persian sources. (López Baralt 2009, p. 1)

The Tarŷumān al-Ašwāq consists of 61 poems, qasidas [kasîdes], which the author himself deciphered in an interpretative key to a commentary on it [al-djhaja ir], where he clarifies some of the symbols and names. Like St. John of the Cross, Ibn 'Arabi performed an exegesis of his own work, which makes it somewhat easier to comprehend. The text, preeminent within the amatory poetry of Muslim spirituality, belongs to the category of epithalamia or love lyrics, part of the cult of beauty. As in the Song of Songs-similarly preeminent within Judeo-Christian wedding mysticism - the poem's plot revolves around a journey through complex geographies. It too is full of amorous nostalgia, intense sensations, laments for the flight of the beloved (the beautiful Nizām), states of intense dejection caused by separation, fleeting encounters, an urgent and longing search that follows a trail full of premonitory signs: birds, winds, mountains, trees, aromas, shops, fountains, roads, caravans, dunes, mirages, flowers, gazelles, fire, gardens, rain, lightning ... It is within this atmosphere that the celestial archetypes manifest, leading on to Knowledge through Love and desire and impelling the seeker to continue the search. She, the Beautiful One, subjugates the enamored traveler, seducing him through fleeting glimpses. Her elusive Presence is located between light and darkness, leading Her pursuer through a world of contrasts and indistinct appearances: 
Even at night, we are next to Her in the light of day/and through the locks of her hair the night turns to day. (Arabî 2002, Cas. XXIX, vol. 8, p. 202)

This poem is as sinuous and difficult as the Zohar and The Spiritual Canticle, and like them, it reflects the painful soliloquy of an amorous soul, the soul of the pilgrim exiled from himself who wishes to apprehend an indefinable Reality: the Beloved. The text proceeds through a plethora of devices: symbolic codes, gnomic and knowing allusions that are suggestive rather than definitive [Isāra]; intimate events expressed through external and literal references [Ibāra]; obscure locutions (Arabî 2002, Cas. XXIX-8, p. 22) in which the hidden sense of words [bâtin] begets the existence of other, unfamiliar scenarios where words full of subtle nuances [latīfa] preside, scenarios that allude to realities [haqiqa] even more substantial than those operative in everyday life. All of these factors complicate the poem's interpretation, even for philologists who are experts in the Arabic Science of Letters ${ }^{16}$. It seems appropriate, therefore, to apply a spiritual hermeneutics [tawîl] in accordance with the revelations inspired by it. This is how the word acquires an existence beyond language, and the poet, an interpreter of himself, is inevitably overcome by what he intends to say.

The experience of an unsatisfied longing leads the author to describe an intense amatory process, a journey through "a shoreless sea" (Arabî 2002, p. 67), during which a restrained force seems to overflow the words themselves. Still, it is through words that he attempts to reveal the discovery [kašf] bestowed by an inner vision [basira] conferred by Wisdom [hikma], which becomes Presence [hadra], thanks to which it is possible to taste [dawq] a deep essential spirituality [rūbanniyya]. It is this deep spirituality that gives access to the secrets of an enigmatic Reality represented by the figure of a young Persian woman, [Nizām], an immaculate virgin. She is a true theophany of the Absolute, a prodigious and beautiful maiden suspended between reality and the interstitial world of creative imagination to which Ibn 'Arabi as the Sage, [Šayj] devotes verses of the highest mystical and symbolic tone. It can be deduced from these words that the true spiritual lover loves with both body and spirit, rejoicing in "the love of the seer, not of the blind" (Arabî 2002, p. 34), It follows that this love "with the entire being" embraces "the entire being of the Beloved". In his Dhakari-al-a'laq (Treasure of the Enamored), an interpretative introduction to the Interpreter of Desires sponsored by his followers, Ibn 'Arabi sets out to counteract the implicit danger of a literal, erotic-amorous interpretation of his verses, insisting explicitly (Arabî 2002, p. 99), that the events described were actually experienced. That is, he speaks about an intimate experience replete with such senses as taste [dawq], inner vision [tabassur], and hearing, associated with the creative word [kun].

It is precisely this inner vision that allows the opening [futuhat] of gateways to another world, an imaginal universe [alam al mithāl] linked to an intermediate plane of reality, the Isthmus, [barzaj], a dimension in which there is a convergence of the corporeal senses with that which transcends them. This is also the site of theophanies and revelations, not unlike the Strange Isles described by St. Jhon of the Cross. The qasidas radiate an elevated symbolic and gnostic content in which it is necessary to highlight the poet's interpretation of the unique transcendent, personal, and non-transferable experience deriving from a theory of "seeing" Knowledge inspired by theosophical forms [maz-hir]. As Henry Corbin maintains (Corbin 1958, p. 13), the poem emphasizes the transmutation of the visible world

16 Ibn 'Arabi, the supreme master (al-Shayj al-akbar) of Sufism, who was influenced by Sahl al-Tustari (818-896), was one of the most the most prominent practitioners of the Science of Letters and dedicated some of his most important texts to it. The Science of Letters or Ilm al-huruf, is a traditional Islamic practice centered on meditations on the symbolism of the letters of the Arabic alphabet, considered according to their mystical significance as hermeneutic keys to every manifestation. The Islamic equivalent to the language in the Jewish Kabbalah, it is based on the correspondence between the process of revelation of the holy book and the creation of the cosmos, with the cosmos viewed as a book. The cosmos is revealed and created through the letters of His names, which are the manifestations of His essence, the archetype of all things and the point of return both for the spiritual path and one's individual path. Therefore, the Science of Letters is closely related to metaphysics, cosmology, and hermeneutics, as well as with the hierarchy (walaya), spiritual ascensions and magic. Ibn 'Arabi (560/1165-634-1240) dedicated some of his most important texts to the Science of Letters.

See: Mora Fernando, Ibn Arabî, Vida y enseñanzas del gran místico andalusí, Ed. Kairós, Barcelona 2011 and Garrido Pilar Clemente, El Inicio de la Ciencia de las letras en el Islam, Ed. Alquitara, Sevilla 2010 
into symbols. The intuition of "something" occurs in an image that corresponds neither to a universal logic, nor to an entity endowed only with earthly senses. Therefore, the symbolic plane refers us to a differentiated dimension of consciousness; it reflects the cipher to a mystery, the only means of saying what cannot be apprehended or explained. The mystery can only be deciphered, and consequently postulates an esoteric knowledge wholly foreign to ordinary evidence. In these qasidas full of antinomies (Arabî 2002, Cas. XXIX, vs. 7, p. 238), paradoxes, contradictory and oscillating sentiments, Ibn 'Arabi describes a spiritual journey along a path that introduces the traveler step by step to a sacred vision of the cosmos that unifies the multiple dimensions of being in a search for the Eternal Feminine: Wisdom. The tracks, the traces, the signs that the Beloved leaves along the way [iša rat], are clues that lead the traveler on towards the goal. These will inevitably differ according to the nature and disposition of the pilgrim, who searches for shortcuts and follows the signs without lingering overlong in the successive states [hal] and stations [maqamat].

The axis of the poem lies in the encounters and dissonances provoked by the fluctuations, absences, and Presences of the Beloved who cannot be seen by human eyes, but beheld only by a supra-sensible apprehension: "Human sight does not reach Him ( . . . )" "It is subtle (... )" (Koran 6,103). The mystic is valiantly seeking the encounter with Her, propelled by the desire for Union. When the traveler reaches the corresponding stage along the way, the veils that cover the face of the Beautiful One are lifted to reveal the dawn, warning of the danger of unmediated vision:

Cast her a glance through that veil/for (the vision) of such splendid beauty is too much to bear (Arabî 2002, Cas. XXIX, vs. 7, p. 238)

When she raises her veil and uncovers her face she dims the brightest lights of morning. (Arabî 2002, Cas. XXVIII, 9, p. 222)

Ah, Moon, who show yourself to us behind a veil/a timid blush on your cheeks!/You veiled yourself, for it would have been torture to behold your face unveiled. (Arabî 2002, Cas. XXV, vss. 5-6, p. 166)

The veils represent the insuperable distances between the diverse planes of Being. Whoever would to travel to "The Dwelling of No-Dwelling", the seventh station, the meeting point, must suffer a symbolic death that presupposes the annihilation of the self [fanā] as a step toward knowledge. The Gnostic [säalik] attains to the Lady's subtle Presence through a tenuous mental perception in which the sacred-ever-present to the spirit-appears far away until it irrupts in the moment of theophany [tayalli $\bar{y} a l \bar{a} l \hat{\imath}$ ]. Only through the development of the spiritual heart $[q \bar{a} l b]$ can the spiritual and material worlds communicate with each other, and the approach toward spiritual knowledge and Wisdom, marked by successive states [hal] and stations [maqām], takes place within this heart.

Just as in the Zohar and the Spiritual Canticle, Solomon is a fundamental reference in the Interpreter of Desires [Tarŷumān], while Wisdom, in the person of Nizām, the beloved object of Ibn 'Arabi"s amorous laments, is a replica of Inanna, the Sumerian goddess praised by Akkadian poet Enheduanna in his 'Nin-Me-Sar-Ra", who is clearly related to Light (Sab. 7, 29-30).

For she is fairer than the sun, outshines every constellation of the stars/Compared to light, she is first of all/though night supplants light, wickedness does not prevail over Wisdom (Salomón 1992, vss. 29-30).

At the end of the day, the radiant Star, the Great Light that fills the sky, the Lady of the Sunset appears in the heavens (Wolkstein and Kramer 1983, p. 101). (Inanna).

You can see her, walking on crystal floors like a sun that mounts the firmament as far as the abode of Hermes (Arabî 2002, Cas. II, vs. 3, p. 107). (Nizām)

The profile of the Lady Wisdom, the object of the search in all three Hispanic spiritual traditions, is remarkably similar in each. She is remote; she inhabits the Mansion of Solitude, drawing near and then withdrawing, seducing the pilgrim by this game. She is elusive and majestic, demanding that her suitor await her patiently. Full of mystery, She is light and 
yet loves darkness and is sometimes deadly, as we will see in the next qasida where Ibn 'Arabi frames the description in this way: "You strike like Apollo's lightning." Her gaze is

The murderous look that kills. The sun of the highest sphere in the bosom of Hermes. It is the Torah, the splendor of Beauty. It is savage, and in its Presence there is no rest. It maddened the sages of our religion, just as it did the singers of the Psalms of David, the Christian monks, and the followers of the Torah. (Arabî 2002, Cas. II, 4,5,7,8, p. 107)

As Henry Corbin says, Nizām is invested with the theophanic function of Beauty, and from this apprehension there arises the idea of the Feminine-Creator not only as an object, but as an exemplary image of the sympathetic devotio of the "faithful lover" [fideli d'Amore] (Corbin 1958, p. 24). She truly possesses the secret of divinity [sirr al rububiya], and she awaits the greeting of a lover maddened by nostalgia. She is the slender maiden whose smile radiates the splendor of the sun ((Arabî 2002, Cas. III-6, p. 111). Ibn Arabî speaks to us of an "orphan and exiled love", "besieged by desires and pursued by swift arrows" (Arabî 2002, Cas. IV-4, p. 113). There is no place for harmony in the time of rupture, and due to mis-encounters, the mountain and the riverbank diverge in a separation that only exacerbates the search for Union [tawhid].

In a verse from sura Fussilat, it is said, "We will make them see Our signs on the horizon and in their souls" (41:53). The meaning of the statement for the Sheikh Al-Akbar is explained in a chapter where he deals with sakina (peace, "serenity", but also, like the Hebrew Shekhinah, the divine "Presence"): "The sakina that God sent down for the children of Israel in the Ark of the Covenant [Qu'ran 2:248]" "was made to come down in the hearts of believers of Muhammad's community [Qu'ran 3:110] ... " (Chodkiewicz 1993, p. 96).

The poetic text tells us of a heart wounded by the grief of absence that wishes to die in the gaze of its Beloved. There are symbolic references common to both Ibn 'Arabi's Interpreter of Desires [Tarŷumān] and Moses de León's Zohar, as well as St. John of the Cross' Spiritual Canticle and Living Flame of Love. One of them is the significant Presence of water, as in "To the Water" (Arabî 2002, Cas. XIII, 2, p. 130), where Ibn 'Arabi refers specifically to the sacred well of Zamzam, near the Ka'aba in Mecca, the meandering streams, the rain, the Living Source (Arabî 2002, Cas. XIII-2, p. 130) the "fire".

Whoever ignites this fire, beware!/This fire of passion belongs to you/take some of its flames too. (Arabî 2002, Cas. VIII, p. 120)

He also tells us of the thickets, the breeze that spreads the fragrant odors, of "Love" among the flowers of the Garden (Arabî 2002, Cas. VIII, p. 121) of the "Ringdove" (Arabî 2002, Cas. XI: vs.1, p. 124), of the thirst for Love, of the "veiled gazelles" whose eyes send signals/who pasture in the breast" (Arabî 2002, Cas. XI, vs. 1, p. 124), of the arāka and bān trees (Arabî 2002, Cas. XI, vs. 12, p. 125). It is worth noting, as well, an erotic reference to hair (Arabî 2002, Cas. VII, 9, p. 118):

When they feel fear they let fall their hair/and with their tresses steal away into the darkness.

In the Zohar and in the Spiritual Canticle, just as in the Sumerian texts, mystical terms refer to the erotic qualities of human life. The instinctive engine that drives the journey is a relentless desire. The mystical itinerary speaks to us of an incarnation of divinity that becomes palpable in all things. The image of the Beloved cannot be captured; it can be seen only in an epiphany, yet it is reflected in nature and in the soul as in a mirror. Language, the mediator between the two planes, is situated on that borderline where the body ends and the spirit reveals itself. The Beloved is the paradigm of intangible beauty and wisdom. The poet must travel far along the path that leads to Knowledge, a trajectory that must be read in terms of Presence/absence (Arabî 2002, p. 19) [hadra/gayba]. The absence of love is fatal, and once the encounter takes place, the heaviest burden of love becomes easy to bear. As in the Spiritual Canticle, the poet in love "dies of love and melts like snow" (Arabî 2002, Cas. XV, vs. 2, p. 135). 
For Ibn 'Arabi, all Creation is essentially a theophany [tajallî], and as such is an act of the divine power of imagination. Accordingly, the organ of active human imagination is identical to the organ of the absolute theophanic imagination itself. The creative act proceeds from the primordial sadness and loneliness of an isolated divine being that impel Him to make Himself manifest in human beings who, in turn, reveal Him to Himself. Divine compassion leads Him to reveal Himself to the creatures through which His Names and attributes will operate and testify to his creative ability and supreme Wisdom. This epiphany is evident in the passage from the state of concealment, of implicit potency, to the luminous, externalized and revealed state (Corbin 1958, p. 139). In short, life results from the dynamism linked to a recurring creation, renewed at every moment and resulting from an incessant theophanic imagination projected through a succession of theophanies [tajalliyât], thanks to which beings are in continuous ascent. The names hidden in the Supreme (the "beautiful noble ones" referred to in sura 59:24), longed to manifest themselves. In a hadith, Allah declares: "I was a hidden treasure and I loved to be known; so I created the creatures ..."

Ibn 'Arabi holds that divine compassion embraces the God created within the creeds (Corbin 1958, p. 91). The Gnostic, however, is faithful to his own Lord, to the divine name with which he is invested. Therefore, each form or path implies a link to a certain phenomenology of prayer [dhikr] that refers to the emergence of the invisible being [bâtin] and its eternal individuality, as manifested through the compassionate and merciful breath in the Worlds of Divinity and Humanity: lâhût and nâsût. Each being is an epiphanic form [mazhar] of the divine being, his Lord, who manifests himself in a creature under one or more divine names (Corbin 1958, p. 93). "The Supreme Secret" has two aspects: The Name manifests thanks to the servant, who is the fulfillment of that pathos. There is, therefore, necessarily a correspondence between the Divine and His creature. This covenant of sympathy exists from pre-eternity, so that once beings come into existence, God praises Himself in all creatures; they are His theophanies. Consequently, the life of the mystic tends to realize this union of simpatheia by which God establishes a dialogue with himself in terms of Love. Ibn 'Arabi describes this beautifully when he says, "All creatures are wedding beds where God manifests Himself". Furthermore, the Andalusian master does not shrink from asserting something that may sound heretical to the ears of the jurist: God is present only insofar as he is recognized (an assertion difficult to reconcile with absolute divine sufficiency). That is the magic of creation. It is precisely such participation that potentiates the perfect human being, Insam al Kamil, who bears all the Names of God and realizes them harmoniously. This concept is also found in Jewish tradition, as well as in Fray Luis de León.

\section{The Light of the Zohar: The Book of Splendor}

With the help of the Zohar we will emerge from exile (89-90): "The wise will shine like the splendor of the firmament" (Laitman 2015, p. 235)

The Sefer ha-Zohar is one of the most representative texts of the Jewish Kabbalah. Like the much older Sefer ha-Yetzirah (the Book of Creation, or alternatively, of Formation), the text applies a metaphysical-poetic hermeneutics of the first moments of creation to the accounts found in the Torah, where the erotic echoes of the Song of Songs resound:

The flowers are blooming, the season of the singing birds has come, and the lullaby of turtledoves fills the air. The fig trees begin to form their fruit, and the fragrant vines are in bloom.

Rise up, my beloved! Come with me, my beautiful woman! (Song of Songs 2:8-13) 
The Sefer Ha-Zohar ${ }^{17}$, hereinafter the Zohar, the greatest recopilation of the Hispanic Kabbalah, is transmitted in a theosophical-theurgic treatise that advocates a mystical path of knowledge and action whose objective is to describe the various manifestations of the God of Israel as implied in the revealed wisdom of the Torah. Not surprisingly, the Zohar, as a kabbalistic text, was long regarded as a cryptic and unapproachable collection of secret knowledge, lacking a necessary exegesis and reserved solely for a minority of rabbinical scholars. It is unanimously acknowledged as "the deepest, darkest, most mysterious, and the principal work of all the books of the Kabbalah" (Laitman 2011, p. 16).

There has been some controversy over the origins of the work, but Gershom Scholem (Wolfson 2001, p. 171), Elliot R. Wolfson, and Moshe Idel, after a rigorous and methodical examination of the historical and philological elements, adhere to Isaac of Acre's theory, which ascribes the work to Moshe ben'em Tob of León. Known to us as Moses de León, he was an outstanding figure within the world of Hispanic Sephardism. Most probably born in León, he lived in Guadalajara and died in Ávila, where some researchers believe that part of the Zohar was written. In Abraham Zacutor's Sefer Yuhasim, Isaac of Acre (Wolfson 2001, p. 171) attests that the work was written by Moses de León. For his part, Yehuda Liebes (Wolfson 2001, p 173) promotes a widely accepted theory that attributes the work not to a single author, but to a mystical group or fraternity operating in Castile under the direction of Moses de León. This group of rabbis and leading Kabbalists would include Joseph Gikatilla (Yosef Chiquitillia) and Abraham Abulafia himself.

Whether the product of a single author or a group of mystics, most researchers agree that the book was written in Castile, and some, like Yitzahak Baer (Wolfson 2001, p. 174), further assert that it is a reflection of the Castilian society of the time. The Zohar, in this view, would be a record of the actual experiences of Jews living in that complex, multi-cultural Spain. Gershom Scholem takes a similar and perhaps more extreme position, maintaining that the authors of the Zohar describe, under a kabbalistic interpretation, a compendium of the habits and customs of the Jewish community in 13th-century Castile (Wolfson 2001, p. 174).

The work purports to consist of the teachings given by R. Simeon ben Yohai in the second century C.E. to a group of his followers hiding in a cave in Galilee during the Roman occupation. Its structure consists of sections and imaginative stories that interpret the Torah. As previously noted, researchers like Yitzahak Baer and Gershom Scholem regard these stories as reflections of the Jewish life of the time, with Scholem claiming that Moses de Leon dressed his interpretation of Judaism in "archaic robes" to make it more acceptable, while Isaac of Acre credits him with having, in a sense, turned the story into a novel to assure that it would be more widely read.

It is worth noting that Michel Laitman is a principal dissenter who prefers to ignore the prodigious and unique Castilian contribution and attributes the Zohar to the author identified as Simeon ben Yohai, declaring that the text remained concealed until "at the right time" (somewhere between 1930 and 1940), when the world was prepared to receive the teachings and his own teacher, Rabbi Yehuda Aslagh, composed the exegetical commentary Ha Sulam ("The Staircase").

In order to penetrate the meaning of the stories related in the Zohar, one must remember that in it the Torah is perceived as a game of enigmatic puzzles through which the

17 Ariel Bension, may be described as the last of the great Jewish Sufis. That is, he was the last of the Kabbalists who was also thoroughly learned in and sympathetic to tasawwuf, and who wrote with deep perception on outstanding Muslim Sufis, as well as on the Kabbalists influenced by Sufism. The most important work of Rabbi Bension is The Zohar in Moslem and Christian Spain (First edition in English: London, G. Routledge, 1932; second edition, New York, Sepher-Hermon Press, 1974. Translations apparently exist only in Spanish and Portuguese.)-written in English with its title referring to the preeminent classic of Kabbalah. Zohar, meaning "Splendor," is known in Arabic as Kitab Al-Zawhar or Kitab Al-Zuhar.

The distinguished 20th C Spanish philosopher Miguel de Unamuno, in his prologue to the 1934 Madrid edition of Bension's work, compared the Zohar with the Castilian classic, Don Quijote, thus underscoring its fundamental literary character. (Miguel de Unamuno, "Prólogo", in Bension, Dr. Ariel, El Zohar en la España Musulmana y Cristiana, Ediciones Nuestra Raza, Madrid, 1934, p. 13).

The brilliance of Rabbi Bension's commentary on the Zohar and its relationship to tasawwuf as well as to Christian spiritual traditions resulted in his election to the Royal Academy of History in Spain, and his book is cited in the bibliography of the most significant work of Jewish metaphysical historiography, Major Trends in Jewish Mysticism by Gershom Scholem. Before publishing his book on the Zohar, Rabbi Bension issued a work in Hebrew in Germany in 1925, deploring the decline of Kabbalah as he perceived it. 
Creator speaks to His people by means of an esoteric numerology of letters, Gematria, in which the secrets of life and of the Universe are first concealed and then gradually revealed by the ascending knowledge of the emanations of divine Wisdom: the Sefiroth, which shape de Tree of Life ${ }^{18}$ (see Figure 1). Any analysis of the work requires the reader to implement a poetic and symbolic hermeneutics and apply them to the elucidations of the Torah performed by the Kabbalists around Moshe de León. The truth is that the "Book of Splendor" speaks to us of a resplendent reality linked to the mystery of divine Wisdom (Sod Hokmah ' $\breve{l o h i t)}$ and to an enlightening gnosis that aims to decipher the most sacred of the divine names: YHWH, the Unity of God. The mystic who "receives" enlightenment, Maśkil, understands with "the eye of the intellect" ('En Ha-Ś $e k e l)$ thanks to a noetic, intuitive, and non-discursive knowledge. This sense of mystical "vision" is as fundamental to Hebrew mysticism as to the corresponding Sufi or Christian version, a fact emphasized by Fabio Samuél Esquenazi (Esquenazi 2020, p. 417 and ss.). Specifically, in the Zohar the ecstatic experience is associated with divine powers that are visualized as refulgent letters inscribed in a book written by God, the Torah, identified with the Tetragram.

Wolfson (2001, p. 165), considers that within the minority group in which the Zohar was born, this mystical interpretation of letters bears an unmistakable imprint of Joseph Gikatilla. ${ }^{19}$.

Concerning the wisdom of the Kabbalah, Wolfson suggests that it may be a theosophical application of what was originally a philosophical concept (Wolfson 2001, p. 169). As Wolfson himself indicates, although Moses de León began as a follower of Maimonides, and particularly his Guide for the Perplexed (an antithesis to the Zohar ${ }^{20}$ ), he subsequently evolved through a process of ecstatic contemplation. This process took the form of the emanating images that shape The Tree of Life, a diagrammatic ordering in which the feminine and masculine components complement each other, constituting a complex geometry through which the sacred manifests in the ten Sefiroth, or planes of being. These Sefiroth are polar powers derived from the sacred tetragram $\mathrm{YHWH}$, and their interplay represents the dynamic and bi-directional flow of the original principle whose objective is to make the Primordial Man, the Adam Qadmon, sprout from the depths of each soul. In this way, the Zohar provides a guide to the spiritual path, a map condensed in the Tree of Life, in which Reality is structured in terms of descending spiritual worlds.

The Tree of Life also corresponds to an anthropomorphic image of the relationship between divine energies. Not in vain "God created man in His image and likeness", and

18 Rabbi Simeon taught many forms of meditation on the spheres. One example of the multiple possibilities he expounded was to imagine the attributes as a series of dancing lights against the branches of the tree. Closing his eyes, the Kabbalist visualized. Epstein, Perle, KABBALAH: The Way of the Jewish Mystic, Shambhala, Boston \& London, 1988. pp. 57-58.

19 Joseph Gikatilla (Yosef Chiquitilla) was originally a disciple of Abulafia; together, the two practiced linguistic Kabbalah, employing gematria, notorikon and temurah, that is, the Hebrew meditation known as Tseruf. Since the letters of the Hebrew alphabet-like those of the Greek-are assigned different numerations that also represent quantities with their consequent inter-relationships, they open a wide gamut of possibilities to the practitioner. This type of speculation also characterizes much of Ramon Llull's study of permutations in Ars Magna, also known as Ars Combinatoria, although that does not necessarily imply the direct influence of Gikatilla, or even of Abulafia's methods.

Gikatilla and Moses de León, in contrast, placed less emphasis on combinations and calculation; instead they applied the linguistic Kabbalah to the theory of emanations, or Sefiroth. Thus, they were able to enter the field of theosophy and immerse themselves in cosmogony and the emanations, or Divine Names, according to the school of Provence and Gerona.

In the third quarter of the XIII century, Gikatilla wrote an extraordinary treatise entitled Gates of Light (Sha'are' Orah) in which he ranks the Sefiroth in inverse order to the previously prevailing arrangement. Almost all of the many earlier texts described them as emanating from the Supreme Principle in several equally sacred stages culminating in the Queen-Bride, that is, Malkuth, the universal receptacle. In opting for an ascending pathway from Malkut to Keter, Gikatilla inverted this order.

See R. Yosef Chiquitilla, El Secreto de la Unión de David y Betsabé, Introduction, translation, notes and the the Hebrew test by Charles Mopsik, Riopiedras Eds. Barcelona 1996.

Rabbi Yoseph Gikatilla, Gates of Light (Sha 'are Orah) translation by Avi Weinstein, Harper Collins Publishers, New York 1994

20 Maimonides' Guide for the Perplexed is based on medieval aristotelianism, tinged with Neoplatonism and with Seneca's Stoic philosophy. It supports creationism and searches for logical Unity, maintaining that reason and revelation coincide. A philosophical and moral guide, it accepts Aristotle's metaphysics, though not his method. The Zohar, in contrast, is an esoteric kabbalistic, and symbolic text that employs a hermeneutical method to interpret the Torah, and is therefore alien to aristotelian logic. Neither systematic nor philosophical, it relies on a poetic, eccentric, mystical, and intuitive rationality unrelated to the methods of medieval aristotelian rational philosophy. In the Kabbalah, biblical texts are analyzed and interpreted with a view to extracting their occult meaning. 
the Hebrew letters form a model equivalent to the structure of a human body, which is identified as the actual celestial metaphysical order, seen through its reflection in a mirror. Thus, the human representation can be understood only in the light of the divine, composed of the letters of the Hebrew alphabet summarized in the Tetragram, a theonym, or proper name of God, the root of the mystical language and essence of the Torah.

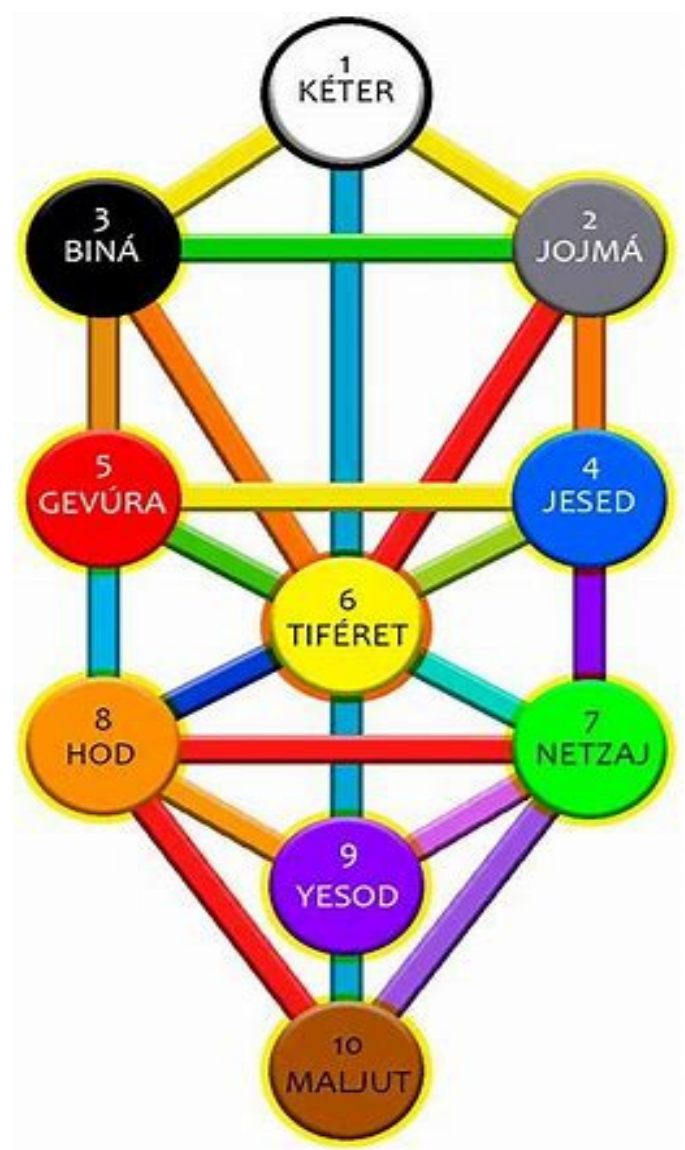

Figure 1. The tree of life.

Aritmosophy is essential to Zoharic rhetoric, just as it is to Sufism. In this sense, we refer to the connotation of the very term Sefiroth, ( $\mathrm{s}_{\mathrm{e}}$ far), "numbers", referring to the separate intellects and linked to each of the celestial spheres (Wolfson 2001, p. 167). The word can also represent sappir (luminosity, sapphire) and sefer (speech, book). Wolfson explains (Wolfson 2001, p. 176) that "no word in English or Spanish can account for all the semantic connotations associated with the term Sefiroth".

The group of planes or Sefirah that Laitman denominates as ZA ${ }^{21}$, Zeir Anpin, (Laitman 2011, p. 31), are located between the upper spheres Keter, Hokmah and Binah; while the lower position, Malkuth, is united around the Balanced Beauty of Tiferet to Yesod (ego sphere), Hod (mental sphere), Netzah (emotional sphere), Yesod (compassion) and Gevurah (severity). As the heart, Tiferet occupies a central place in the Tree of Life, replica of the human being. It is in Tiferet that the spiritual correction of the process occurs, and thus it is the culmination of the lower Sefiroth.

Therefore, taking ZA into account, the Sefiroth can be reduced to five. Keter (the Crown, first Sefirah) represents the pure potential of any manifestation. Prior to all mental processes, it cannot be captured by thought, and it occupies a central position in the Tree. Hokmah (Unlimited Wisdom) is the second Sefirah and the first intermediate step between Keter, the Crown, and the other Sefiroth. It represents the primordial idea. Binah (black as the womb

21 Malkuth can realize a zivug (coitus, sexual union) with ZA and thus receive the Light of Hokmah. 
where life thrives) is the rational process and the limitation of Hokmah. ZA represents the meeting of the five Sefiroth previously mentioned in Tiferet with Malkuth. The last of the 10 Sefiroth, Malkuth symbolizes the desire to receive for oneself. It is the lowest layer of manifestation and corresponds to the human being). All the Sefiroth are interconnected, and each of the 10 Sefirah includes all the others within itself. Each, in turn, consists of ten sub-Sefiroth.

The process of knowledge is as follows: ZA requests the Light for Malkuth from Binah, who receives it from Hokmah, the depository of the Creator's Light; and subsequently "the opening of the eyes" occurs in Malkuth. During this entire process, it is imperative to "listen" to action, and then "the eyes" will rise from Malkuth to Hokmah, in a return to the Creator. The "One who opens the eyes" is MI, and above Him no questions remain. In this process Hokmah, the seed of creation, acts through Binah which is placed under Hokmah and transfers the Light to Malkuth, the feminine recipient. Malkuth must rise up to Binah, who receives the Light of Hokmah. Once Malkuth (thanks to the fact that Keter and Hokmah descend toward her) "becomes equal to" her husband with "the opening of the eyes", she rises beside Him to AVI (Hokmah and Binah), where the spouses are enveloped in its Light.

As we have previously indicated and as we will later see, the erotic echo of the Song of Songs continues to resonate through the text attributed to the circle of Moses de León. Thus, we can affirm that the axis of the Zohar is articulated around a polar structure of the single divine principle in the form of a couple. This polarity implies a theosophical sensuality in which the feminine power acquires supreme relevance, as a luminous beacon and complementary creator of the unreachable and unspeakable essence. It is this that allows the human soul redeemed from exile and vivified by the Light of Wisdom, after a relentless search, to fully adhere to the incomprehensible primal Force,

Under the auspices of the two polarities, male and female, and full of encounters and dis-encounters, laments, compliments, and seductions, the search is marked by the tireless and desiring vivacity of the spiritual Sapience, the Divine Presence or Glory of God: the Shekhinah. She loves secrecy, enigma, and concealment, as can be seen in the discourse that Simeon ben Yohai develops from the parable of the princesses (Ex. 21-24), the principal passage of the Zoharic story of the Princess who is identified with the Torah, pure love.

The Torah can be compared to a beautiful and majestic maiden who is held in an isolated bedroom of the palace, and has a lover of whose existence only she is aware. For her love, he continually passes by the bars and looks around in all directions to discover her.

She knows very well that he is forever hanging around the palace and what does she do about it? She opens wide a small door in her secret bedroom, for an instant reveals her face to the lover, and then quickly retreats. Only he, no one else, is aware of this; but he knows that it is out of love that she has revealed herself to him, and his heart, soul and everything within him are directed towards her. (Sholem n.d., p. 30)

A striking characteristic of this parable is the way in which it addresses themes identical to those of Ibn 'Arabi and Saint John of the Cross, two other Hispanic mystics, as well as the frequency of symbols common to all three: signs, messengers, locutions behind the veil, and glimpses. In all of them, there is a traveler who gradually progresses along a journey motivated by longing, and as he progresses, a "maiden" appears, hinting at some of the secrets behind the veil. The Zoharic story speaks of a beautiful princess (reto behimatá = beloved) who, concealed in her palace, cries out for the love of her lover (rehimáh) and in her lament brandishes her seductive weapons. Her goal: a union in marriage. This account, replete with a powerful and archaic symbolic density, emphasizes the game of concealment and incitement that constitutes the axis of the "journey" in both Ibn 'Arabi's The Interpreter of Desires and the Spiritual Canticle of St. John of the Cross. 
In this sense, Fabio Samuel Esquenazi ${ }^{22}$ conducts an extremely refined hermeneutics of the Zohar. In lingering over a particularly enigmatic Zoharic story, the "Maiden without Eyes" (the Torah in this example) he refers us to Is. 43,4. The exegete is the sage "full of eyes" (Esquenazi 2020, p. 432) who knows how to decipher the riddles of a serpent that flies through the air with an ant lodged in its mouth; of an eagle that inhabits a tree that never existed, from whose nest were stolen eaglets as yet unborn, and which remain, still uncreated, somewhere; and the enigma of the maiden without eyes, whose body is both hidden and revealed, who emerges in the morning, is in hiding during the day, and is adorned with non-existent ornaments. The ancient rabbis considered the Torah to be the Shekhinah herself, the manifestation of Yahweh's Presence in the world, not only as the wife, bride, or daughter sent into exile by the King in the context of the Jewish symbology of exile, but as a maiden who "has no eyes", or has cried her eyes out on account of the loss of her homeland (Esquenazi 2020, p. 432). This celestial sexual polarity in which the metaphysical senses of sight and hearing become more acute, is in all these terms consubstantial with the human being. As a reflection of the supernal entity, and like Her, the human being conjugates within itself both the masculine and feminine.

Consequently, our world as a whole is a mirror, a reflection of what occurs in metaphysical realms, in boundless spaces in which the entire existing universe is combined in pairs, as implied by the Pythagoreans with their list of opposites. That said, the whole of the Zohar can be seen as a wager on the Union of those opposites without synthesis or annulment of the extremes; it envisions the coupling of different elements in the One. To know oneself involves discovering the complexity and concurrence of opposites within an identity that is assumed as one's own, and to this end, metaphysical vision and hearing are activated.

The Zohar says:

Man is the inclusion of masculine and feminine, for he in whom masculine and feminine are joined is called, "Adam" and then worships God. Moreover, there is humility in him. And even more, there is mercy in him. (Laitman 2015, p. 221)

Upon the arrival of the Messiah (the Union in Light, or the reception of supreme Knowledge), humanity, the Eyeless Maiden, will abandon spiritual exile, which is linked to the self and to the destruction of the Temple. Access to transcendent knowledge requires irradiation and luminous reception in each of the souls that act as "vessels" brimming with the desire to receive: that is what the term Kabbalah means.

Thus, the content of the work deals with the loving relationship of the human being with his Creator, through the mediation of his wife, who assumes various identities: Wisdom; Shekhinah (Presence of the Glory of God); Binah (understanding and delimitation of the Light); Keneset Yiśra' el (The Community of Israel); and Malkuth (the human being). The feminine, Wisdom, is the Creator of life both in heaven and on earth and in the Zohar the earthly is a reflection of the heavenly. The heavenly copulation (Zivug) means the union of the supernal spiritual male and female, from Light to Light. (Zohar, 201): "The union of the sexes in this world will be from body to body, and the righteous who follow the right path "are rewarded with the pleasures of that world" (Laitman 2015, p. 219). (Zeir Anpin, the masculine, joins Nukva, the feminine = Malkuth, once it has descended to the last step.)

Ishah, woman, means Esh, fire of the Creator, Alef-Shin, and this fire is connected with the letter Hey, which is Nukva (Laitman 2015, p. 216), the feminine, plenitude of the left enlightenment due to the irradiation of the male Sefiroth Hokmah. Thus, the feminine receives the "luminosity of Hokmah" (Or Hokmah Hasidim), and from that "reception" (Lekabel=Kabalha) arises a similarity (Laitman 2011, p. 107) to the Creator, derived from the enjoyment of pleasure in the Union. "And the Light of the Creator will turn to fire" (Laitman 2015, p. 216).

22 Esquenazi, Fabio Samuel "Ya bien puedes mirarme después que me miraste". "Isomorfismo de la visualización divina en la parábola de la hermosa doncella sin ojos de Zohar" II, 94b-95a and in stanza 24 of St. John's Spiritual Canticle" http:/ /www.2010.cil.filo.uba.ar/sites/2010.cil.filo.uba.ar/ files /186.Esquenazi.pdf (accessed on 2 September 2020). III World Congress Cántico Espiritual, CITeS, Ávila, Sept. 2019. 
Zohar 146 states that when the Sefiroth Sefira Binah, located on the left, which represents the understanding that comes out of Eden, and Hokmah, the Light of Wisdom on the right, come together under Keter, the Crown of the Tree of Life, they adhere to the world of Malkuth in Love. Therefore, the Congregation of Israel, the Nukva, ${ }^{23}$ the wife, appears in the Zohar (Laitman 2015, p. 207) as the bride of the Song of Songs. "Thus, the Congregation of Israel said, set me as a seal upon your heart (Zohar 731) because "Love is strong as death" (Zohar 732) (Laitman 2015, p. 207).

Another line from the Song of Songs $(1,2)$ collected in the Zohar (371), says: "He will kiss me with the kisses of his mouth" (Laitman 2015, p. 204). Laitman/Aslach (Laitman 2015, p. 204) interprets this verse ${ }^{24}$ as King Solomon's words expressing the love between the higher world, Zeir Anpin, and the lower world (ZON) composed of all the Sefiroths linked to Tiferet and the last Sefiroth of the Tree of Life, Malkuth. One spirit adheres to another with a "kiss" and "the kiss on the mouth is the entrance and exit of the Spirit". When the kiss occurs, the Union is sealed.

The wife is the essence of the house, (Zohar, 231) and when "the house is corrected", the masculine and feminine are also corrected, and then the masculine comes to the Nukva, and they join together (Laitman 2015, p. 216). Laitman/Aslagh (Laitman 2015, p. 205) refers to another fragment of the Zohar (70): "See life with the woman you love", in which "the woman you love" denotes the Congregation of Israel, the Nukva, because love is written about her; and it is linked to Mercy, the sefiroth Yesed, on the right side of the Tree of Life. The Assembly of Israel assumes the role of wife of the divinity, just as the Church does when it becomes the bride of Christ. However, when the community disobeys the Creator's precept, the Shekhinah retires, and the exile and rigor of the masculine prevail over Mercy.

In this respect, there is a curious paragraph (327) in the Zohar referring to women. When Israel deviates from its path, the prophet says,

Indolent women, how can they be calm? Why do they remain seated and do not wake up the world? Stand up and rule over men. (Laitman 2015, p. 218)

A further mention of the feminine souls in the Zohar (195-202) describes six Palaces of feminine souls and four others that are hidden (Zohar 201): the ten Sefiroth. Every midnight all the Palaces, both heavenly and terrestrial, are gathered together (Zohar, 201) in the heavenly and terrestrial coupling (Zivug):

I was shown six palaces with various pleasures and delights in the place where the curtain is displayed in the garden, since no man may enter beyond that curtain $(\ldots$ ) There are four hidden palaces of the holy mothers that were not taken into exile. Every day they are alone. (Laitman 2015, pp. 218-19)

The Zohar (145-147) also reproduces the Palace of Love (Laitman 2015, p. 205): the Temple, Paradise, the Garden, the PaRDéS. Everything is founded on amorous coupling. When the higher, Zeir Anpin, and the lower, Malkuth, adhere to each other, they do so in love as "the groom and the bride" (Laitman 2015, p. 205). Thus, it is within that coupling that the connective game of the Hebrew letters composing the theonym YHWH (Yod, Hey, and $\mathrm{Vav}$ ) is created through Love (Zohar, 147).

As we can see, the awakening of desire and passion permeates many of the stories that compose the Zohar, which continuously refers to the secrets of the Wisdom of the Hidden, inevitably surrounded by a halo of mystery in which Love is the force that drives the progress toward Knowledge and the consequent annulment of the individual. Since

23 "When the Zohar speaks of the Shekhinah as feminine-it quite frequently uses the term 'alma-de-nukva, "the world of the female" in this connectionthis is more than a mere circumlocution for the passive and receptive elements among the divine attributes".

"... for him [the author of the Zohar], as for other Kabbalists, the Shekhinah is regarded as the "celestial Donna;" (ha-isha ha-'elyonah; cf.II, 54b) or the "Woman of Light"(iteta da-nehora), in whose mystery are rooted all the females in the earthly world. In brief, she is the eternal feminine".

"But the feminine quality of the Shekhinah is understood, first and foremost, and emphatically, in her role as female partner in the sexual union, zivuga kaddisha, whereby the unity of the divine potencies is realized through the union of male and female". See (Sholem 1991, chp. 4).

24 Ibid., p. 204. 
Love signifies death to mundane reality, it is rebirth to another life; it "opens the eyes" while at the same time blinding the eyes of reason.

The Zohar also speaks of rupture, of heartbreak (344), of the exile of the Shekhinah, Wisdom, the Glory of God, on the day the Temple (Paradise) was destroyed and Israel went into exile. The proverb of the King and the Queen (Laitman 2015, p. 229) (Zohar 78-81) deals with the King's anger at his queen, whom He expelled from his palace for having distanced herself from Him. Nevertheless, in His desire for union, the King sought her out, lifted her up, and took her back to His palace, swearing that He would never part with her again. Thus, the Congregation of Israel awaits the wife, so that He will come and take her by the hand, lifting her up and reconciling with her.

In clear correspondence with the Christian gnosticism of the first centuries it says

"The divinity was expelled from the King's house". "When she descended she saw that her abode had been destroyed (...) and the sacred Palace and house burned by fire" (Zohar 345). "And then she raised her voice in lament ( ...) because the holy King ascended and is not there" (Laitman 2015, pp. 224-25). All the passion of the wife, Israel, is concentrated in a desire to keep the Shekhinah from leaving, wishing that instead she run like the "deer or a little antelope", turning her head back towards the place where she was before: in the heart of His servant.

The Shehkinah is also the place where the mystic experiences the Creator. She is associated with the Rose, in which Elohim is present in the 13 petals (13 attributes, 13 words) that encircle and protect the assembly of Israel, and in five sepals (equivalent to so many other "doors" and to the five fingers that raise the cup of blessing: The Rose). In another pre-Zohar text, Orzaru'a, "Light Sown" referred to by Wolfson (2001, p. 168), Moses de León highlights the word Ehad, which refers precisely, though cryptically, to those thirteen attributes:

The secret of the Kabbalah is explained by another secret, that of the matter of the thirteen attributes, thirteen letters $(6,4)$ and one left over, 'Alef, which is the number One, which corresponds to the One, 'Ehad'. (Wolfson 2001, p. 169)

He, the bridegroom, is the Secret (Laitman 2011, p. 41), but who is He? The one who "opens the eyes". $\mathrm{MI}=\mathrm{Who}{ }^{25}$ has created this and is found along a hidden path and does not reveal himself and receives the name MI, the extreme end of heaven. The human being in the last degree, Malkuth, asks: MA = What are the heavens and the created earth, that is the testimony that lies in the wife, Jerusalem, the quintessence of beauty. So MI is the upper end of the sky, as MA is the lower, to which the Light (Or) of Hokmah, which illuminates Binah, descends, in order that Wisdom may penetrate Malkuth.

A deep structure arose from a thought (a point that ascended, when the occult wished to reveal itself) and is called MI, principle of the erected structure, reserved in the most unfathomable of the Names, the Tetragram. He wished to reveal himself: ÉLEH: ELOHIM, that is the name that ascended. (Laitman 2011, p. 42)

The Rose (Malkuth), which is the assembly of Israel, rests upon and is sustained by the union of these letters: ÉLEH and MI.

I am a rose of Sharon, a lily of the valleys" [Song 2:1] (...) the Community of Israel is called the rose of Sharon because its desire is to be watered by the deep spring that is the source of all spiritual rivers, it is called the lily of the valleys. And also because it is in the deepest place it is called lily of the valleys. At first, she is a rose with yellowish petals, and then a lily of two colors, white and red, a six-petalled lily that changes from one hue to another. She is called "pink" when she is about to meet the King, and after she has joined him in their kisses, she is called "lily". (Sholem n.d., p. 41)

25 As for the interpretation of the Zoharic text, specifically of the Tree of Life, we continue Laitman's exegeses, supported by Yehuda Aslagh and reviewed in his work. 
The Creator is the Source of Light and of Pleasure; and the Kabbalah, which dismantles the self into parts and comes from the verb Lekabel, to receive, is a way to absorb that Light from the Creator by providing an explanation of the way, an indicative map of the world (Olam) (Sholem n.d., p. 49), In which the concealment (Ha Alamá) of the Light occurs. The desire for love invites one to receive the invisible in the heart through a continuous transformation and transmutation, a gradual process of approaching from MAN to MI, where the Light resides. The human being has been created to voluntarily acquire that desire for elevation.

It is, finally, this map of the process of occultation, along with the corrective process of "receiving the invisible in the heart", that is described in the Zohar through the means of the Tree of Life and its Sefiroth, as well as through its illustrative and often mysterious parables. Emerging from the land of Castile and from Moses de León's mystical visions, the book creates a metaphysical realm that requires elucidation by the techniques of aritmosophy, hermeneutics, and the tradition of rabbinical interpretation. Following these clues, however, one finds that it depicts a spiritual pathway to mystical union with ancient roots, one that is quintessentially present in the Song of Songs, from which it entered the Christian tradition, but is also found in Ibn 'Arabi and other Sufi mystics. Ultimately, the soul is similar to a vessel, a womb, that wants to be filled with Light and the coming of the Light is determined by desire and interrogation. Thus, the Zohar offers, in addition to its many challenges, a vision of light and a source of inspiration.

\section{Conclusions}

The force behind the metamorphosis that leads to the Union of differences is both Himma, the creative energy referenced by our Sufi master Ibn 'Arabi and also the Shekhinah, the Presence and Glory of the Lord in the Kabbalah. This feminine energy, directly linked to the creation of beings, assumes several names and genders. She is the hidden secret. She is the Duende. Only those who are capable of "glimpsing" Her own incommensurable dimension may contemplate the Lady of the Numbers who dwells in the sacred geometry of the abyss, concentrated in a single point within the depths of the human heart. The hermetic, allusive, clandestine, and poetic Word, pregnant with gnostic resonances and musical murmurs, sweeps the "pilgrim" along with it on paths that cross and bifurcate at mysterious points before leading to an ancient, luminous knowledge. Once arrived, the seeker is introduced into the "germinal vessel", the "inner sanctum", the Initium, the Matria. She is Nizam [Harmony], and also Hokmah [the ninth Sepher, in the Tree of Life, full of light and Malkuth]; She is Wisdom in Proverbs 8, the Mater de filius sapientae, who through an alchemical transmutation becomes a song to Sophia, both absent and present throughout the Creation.

Sophia is diffused throughout the cosmos, in all living things. She trembles with the impetus of a desire freed from ego which demands access to this redemptive Force, pregnant as it is with a knowledge capable of raising the human being exiled from its true self into unsuspected dimensions. The Lady is dynamic and manifests in a "creation that renews itself each instant, in an incessant succession of theophanies" (Chittick 2003, p. 138). She remains veiled to the sight of the multitude, and yet She longs for transparency, even as She retreats. She potentiates a rebirth at every instant. She is the fruit of Divine Compassion (Corbin 2015, pp. 106, 109, 110), opposed to the masculine rigor that rules the normative religions. She manifests in the infinite diversity of the creatures whose function is to adore the Creator. She lives within us, yet is elusive. She is the Lover and the Beloved. She may assume all forms, being both Lord and, simultaneously, Lady. She promotes hidden encounters in pleasant gardens, accompanied by silent music and sonorous solitudes that continuously vibrate in the Temple, the $K a^{\prime} a b a$ of the heart.

Funding: This research received no external funding.

Conflicts of Interest: The author declares no conflict of interest. 


\section{References}

Arabî, Ibn al. 2002. El Intérprete de los deseos, Tarŷumān Al-Ašwāq. Murcia: Editora Regional de Murcia.

Bachelard, Gastón. 2000. Poética del Espacio. Argentina: Fondo de Cultura Económica.

Borges, Esteves Paulo. 2008. Da Saudade como via de libertação. Lisboa: Quidnovi.

Chittick, William C. 2003. Mundos Imaginales, Ibn Arabî y la diversidad de las creencias, 1st ed. Madrid: Mandala.

Chodkiewicz, Michel. 1993. An Ocean without Shore: Ibn 'Arabi, The Book, and the Law. Translated by David Streight. Albany: State University of New York Press.

Corbin, Henry. 1958. L'Imagination créatrice dans le soufisme d Ïbn Arabî. París: Flammarion.

Corbin, Henry. 2015. Acerca de Jung, el budismo y la Sophia. Madrid: Siruela.

Cruz, San Juan de la. 2002. Obras Completas. Madrid: Biblioteca de Autores Cristianos.

Esquenazi, Fabio Samuel. 2020. Cántico Espiritual. In Las Parábolas del Zohar y sus Resonancias en el Cántico Espiritual. Edited by Grupo Editorial Fonte-Monte Carmelo-Universidad de la Mística-CITeS. Ávila: CITeS.

Farré, Miguel Morey. 1998. Available online: https:/ / dialnet.unirioja.es/servlet/articulo?codigo=5757574 (accessed on 13 June 2020 ).

Idel, Moshe. 2009. Cábala y Eros. Madrid: Siruela.

Kingsley, Peter. 2016. En Los Oscuros Lugares del Saber. Vilahur: Atalanta Edic.

Kramer, Noa. 2010. La Historia empieza en Summer. Madrid: Alianza Edit.

Kramer, Noah. 2001. El matrimonio sagrado. Sabadell: Ed. Ausa.

Kramer, Noah, and Diane Wolkstein. 1983. Inanna Queen of Heaven and Hearth. New York: Harper \& Row Publishers.

Laitman, Michael. 2011. El Zohar. Toronto: Laitman Kabbalah Publishers.

Laitman, Michel. 2015. Abriendo el Zohar. Toronto: Laitman Kabbalah Publishers.

López Baralt, Luce. 2009. Simbología mística musulmana en S. Juan de la Cruz y Sta. Teresa de Jesús. Available online: http: / / www.cervantesvirtual.com/obra-visor/simbologa-mstica-musulmana-en-san-juan-de-la-cruz-y-santa-teresa-de-jess-0 / html/021e4a2a-82b2-11df-acc7-002185ce6064_11.html\#I_0_ (accessed on 20 July 2020).

López Baralt, Luce. 2020. Asedios a lo Indecible, S. Juan de la Cruz canta al éxtasis transformante. Madrid: Trotta.

Lorca, Federico García. 2003. Juego y Teoría del Duende. Available online: https:/ / biblioteca.org.ar/libros/1888.pdf (accessed on 22 July 2020).

Mora, Fernando. 2019. El Perfume de la existencia. Córdoba: Almuzara.

Patai, Raphael. 1947. Man and Temple in Ancient Jewish Myth and Ritual. New York: Nelson \& Soons.

Pessoa, Fernando. 2001. Alberto Caeiro, Poesia. O Pastor de Rebanhos. Lisboa: Assírio\&Alvim.

Ryan, Kerry. 2008. HIEROS GAMOS: Sacred Sexuality Ancient and Modern. How Is Sacred Sexuality Manifesting in a Current Western Milieu and What Is the Emerging Role of the Modern Day Sacred Prostitute? Available online: https: //www.academia.edu/10272231/HIEROS_GAMOS_Sacred_Sexuality_Ancient_and_Modern_How_is_sacred_sexuality_ manifesting_in_a_current_western_milieu_and_what_is_the_emerging_role_of_the_modern_day_Sacred_Prostitute (accessed on 20 August 2020).

Salomón. 1992. Sabiduría 7. Available online: https:/ / www.bible.com/es-ES/bible/442/WIS.7.dhhed (accessed on 3 August 2020).

Sholem, Gershom. n.d. El Zohar; el Libro del Esplendor. Available online: http:/ / www.72.jaimegalo.tv/Zohar.pdf (accessed on 20 July 2020).

Sholem, Gershom. 1991. On the Mystical Shape of the Godhead: Basic Concepts in the Kabbalah. New York: Schocken Books.

Vázquez, Ana. 2007. Historia del Mundo Antiguo Vol. I (Próximo Oriente). Madrid: Sanz y Torres.

Vázquez, Ana. 2016. Available online: http://www.uned.es/geo-1-historia-antigua-universal/ACADIOS/ESHEDUANNA_1.htm (accessed on 20 May 2020).

Wolfson, Elliot R. 2001. Moisés de León y el Zohar. Cuenca: Pensamiento y Mística Hispanojudío y Sefardí.

Wolkstein, Diane. 1983. Inanna. New York: Harper Collins.

Wolkstein, Diane, and Samuel Noah Kramer. 1983. Cantos e Himnos de Sumeria. Available online: https:/ litsdelaant.files.wordpress. com/2013/03/e2809ccantos-e-himnos-de-sumeriae2809d.pdf (accessed on 21 August 2019).

Yom, Tov Assis, Idel Moshé, and Senkman Leonardo. 2006. Ensayos sobre Cábala y Misticismo Judío. Buenos Aires: Edic. Lilmod. 